\title{
Comparative study of fetomaternal outcome using new screening criteria of serum TSH for diagnosing hypothyroidism in pregnancy
}

\author{
Shiva Kumar H C Hiriyur Chidanandaiah, Chandrashekhar T Tharihalli, Suman Gaddi, \\ Chandrashekhar K
}

Correspondence: Dr Chandrashekhar T Tharihalli, Professor, Department of Obstetrics and Gynaecology, Vijayanagara Institute of Medical Sciences,Bellary,Karnataka, India; Email - cstobg@gmail.com

Distributed under Attribution-NonCommercial-ShareAlike 4.0 International (CC BY-NC-SA 4.0)

\begin{abstract}
Objectives: To assess the maternal and fetal outcomes using new screening criteria with upper serum thyroid stimulating hormone (TSH) cut off as $>3 \mathrm{mIU} / \mathrm{L}$, for diagnosing hypothyroidism in pregnancy. Materials and Methods: This study was a cross sectional study, carried out in the department of Obstetrics and Gynaecology. During one year of study period from February 2016 to January 2017, pregnant women with $\leq 20$ weeks gestation, attending antenatal OPD were included in the study and they were followed till delivery. On the basis of serum TSH level, women were divided into study group with serum TSH level between 3.1 to $6 \mathrm{mIU} / \mathrm{L}$, (new range to be studied) and an equal number of ages and parity matched control group with serum TSH levels between 0.4 to $3 \mathrm{mIU} / \mathrm{L}$. The maternal and fetal outcomes were compared between study and control groups. Results: During the study period, in study group 96 women had serum TSH between 3.1-6 mIU/L. Maternal and fetal outcomes in both the groups were comparable. Study did not find any difference in the rate of spontaneous abortion between women in study and control group [ $p>0.99]$. There was no significant difference in the maternal complications like preeclampsia, gestational diabetes and placental abruption in the study and control group. Vaginal delivery and caesarean section were similar in both the groups. Study shows no significant difference of foetal outcome in study and control group [ $p>0.05]$. Conclusion: As compared to pregnant women with serum TSH levels $<3 \mathrm{mIU} / \mathrm{L}$, women with serum TSH levels between 3.1-6.0mIU/L had no significant adverse fetomaternal outcome.
\end{abstract}

Keywords: Thyroid disorders, screening in pregnancy, serum TSH, fetal outcome.

At all stages of life optimal functioning of thyroid gland is essential, including pregnancy and fetal development. In pregnancy thyroid disorders are the most common endocrinological disorder. The prevalence of hypothyroidism in pregnancy is 0.3 to $11 \%$. Subclinical hypothyroidism is more common than overt hypothyroidism $(\mathrm{OH})$. But thyroid disorders present with nonspecific symptoms and clinical diagnosis is often missed because of the hypermetabolic state of pregnancy ${ }^{1}$. Serum thyroid stimulating hormone (S TSH)

Received: $27^{\text {th }}$ July 2018. Accepted: $16^{\text {th }}$ October 2018.

Hiriyur Chidanandaiah SKHC, Tharihalli CT, Gaddi S, Chandrashekhar K. Comparative study of fetomaternal outcome using new screening criteria of serum TSH for diagnosing hypothyroidism in pregnancy. The New Indian Journal of OBGYN. 2019; 5(2): 126-30 
level estimation, thus plays a very important role in the evaluation of maternal thyroid status ${ }^{2,3}$.

Euthyroid status in pregnancy is important for both the mother and the fetus. Fetus is dependent on the mother for the thyroid hormones in the first trimester, for its optimal growth and development. Decrease in thyroxine during this period will impair its neural development. Adverse pregnancy complications like abortion, preterm birth and placental abruption are more often encountered in maternal hypothyroidism ${ }^{3-5}$. The thyroid function tests are significantly affected by physiological changes of pregnancy. Hence Thyroid function test results of healthy pregnant women vary from that of non pregnant women. Hence, the diagnostic criteria of hypothyroidism on the basis of S TSH level during pregnancy have been changing. In the past S TSH values of 4.0-6.0 mIU/L were considered normal. Recent research suggest that first trimester values $>2.5 \mathrm{mIU} / \mathrm{L}$ and second and third trimester values $>3 \mathrm{mIU} / \mathrm{L}$ are associated with adverse fetomaternal outcome ${ }^{6,7}$. By using the classical non pregnant range, one might misdiagnose those women as euthyroid who actually have a slight S TSH elevation ${ }^{6}$. American Thyroid Association (ATA) Guidelines also recommend that for women on L-thyroxine therapy, S TSH should be aimed at $<2.5 \mathrm{mIU} / \mathrm{L}$ in the first trimester and $<3 \mathrm{mIU}$ in second and third trimester ${ }^{7}$. However,in the Indian pregnant women, higher trimester specific reference ranges have been reported ${ }^{8}$. Inspite of these conflicting observations, Indian researchers have reported improvement in the fetomaternal outcomes when pregnant women with $\mathrm{S}$ TSH $>3 \mathrm{mIU} / \mathrm{L}$ were considered hypothyroid and received treatment with L Thyroxine ${ }^{9}$. Keeping this point in view, the present study was planned to compare the maternal and fetal outcomes using new screening criteria with upper S TSH cut off as $>3 \mathrm{mIU} / \mathrm{L}$, for diagnosing hypothyroidism in pregnancy.

\section{Materials and Methods}

This was a cross-sectional study, carried out in the department of Obstetrics and Gynaecology of VIMS, Bellary. After approval from institutional ethical committee and taking patients consent after counseling, the study was started. It was a one year prospective study from $1^{\text {st }}$ February 2016 to $31^{\text {st }}$ January 2017 . During the study period, pregnant women with $\leq 20$ week gestation, attending antenatal OPD from February 2016 to January
2017, planning to deliver at this institute and willing to comply with the study protocol were enrolled and they were followed till delivery.

\section{Exclusion Criteria}

1. Chronic medical disorders,

2. Known thyroid disorder,

3. Bad obstetrics history with a known cause

4. Multiple pregnancies

Along with routine antenatal investigations, serum thyroid stimulating hormone (S TSH) assay was done. On the basis of S TSH level, women were divided into study group with S TSH level between 3.1 to $6 \mathrm{mIU} / \mathrm{L}$ (new range to be studied) and an equal number of age and parity matched control group with S TSH levels between 0.4 to $3 \mathrm{mIU} / \mathrm{L}$. Women with $\mathrm{S}$ TSH between 3.1 to $6.0 \mathrm{mIU} / \mathrm{L}$ were tested for $\mathrm{S} \mathrm{FT4} \mathrm{and} \mathrm{the} \mathrm{reference} \mathrm{range}$ of $0.89-1.76 \mathrm{ng} / \mathrm{dl}$ was taken as normal.

After obtaining informed consent and taking a detailed history, examination was done; women in the study group, treatment was not initiated. The women were followed till delivery as per the routine hospital protocol.

The maternal outcomes compared between study and control groups were

1. Spontaneous abortion

2. Gestational hypertension

3. Preeclampsia

4. Gestational diabetes mellitus

5. Abruptio placentae

6. Mode of delivery

The fetal outcomes studied were

1. Intrauterine growth restriction

2. Prematurity

3. Fetal distress

4. Low APGAR at 5 minutes

5. Neonatal intensive care unit (NICU) admission

6. Intrauterine fetal death and still birth

Data were analyzed using pearson chi-square test. The significance level was set at $p<0.05$. Statistical analysis was performed with SPSS 20.1 for windows.

\section{Results}

A total of 96 women with S TSH between 3.1$6.0 \mathrm{mIU} / \mathrm{L}$ were registered in the study group. Equal number of age and parity matched women were included in the control group. The mean age of women in study and control groups were 25 and 24 years, respectively. In 
Table 1 : Maternal Outcomes in the study and control group

\begin{tabular}{llllll}
\hline Maternal Variables & \multicolumn{2}{l}{$\begin{array}{l}\text { Study Group }(\mathbf{n}=96) \\
\text { Number }\end{array}$} & $\begin{array}{l}\text { Control Group }(\mathbf{n}=96) \\
\text { Pumber }\end{array}$ & P value \\
& 2 & 2.08 & 2 & 2.08 & \\
\hline Spontaneous abortion & 1 & 1.04 & 2 & 2.08 & $>0.99$ \\
GHTN & 4 & 4.16 & 2 & 2.08 & 0.99 \\
Pre-eclampsia & 5 & 5.20 & 2 & 2.08 & 0.44 \\
GDM & 1 & 1.04 & 0 & 0 & $>0.99$ \\
Placental abruption & GHTN - Gestational hypertension, GDM - Gestational diabetes & \\
\hline
\end{tabular}

Table 2: Fetal Outcomes in study and control groups

\begin{tabular}{|c|c|c|c|c|c|}
\hline \multirow{2}{*}{$\begin{array}{l}\text { Fetal } \\
\text { Variable }\end{array}$} & \multicolumn{2}{|c|}{ Study Group $(\mathrm{n}=96)$} & \multicolumn{2}{|c|}{ Control Group $(n=96)$} & \multirow[t]{2}{*}{ P value } \\
\hline & Number & Percentage & Number & Percentage & \\
\hline Prematurity & 3 & 3.12 & 1 & 1.04 & 0.62 \\
\hline IUGR & 10 & 10.41 & 7 & 7.29 & 0.44 \\
\hline Foetal distress & 15 & 15.62 & 12 & 12.5 & 0.53 \\
\hline IUFD & 3 & 3.12 & 1 & 1.04 & 0.62 \\
\hline Still birth & 5 & 5.20 & 3 & 3.12 & 0.72 \\
\hline Low APGAR at 5 minute & 6 & 6.25 & 2 & 2.08 & 0.27 \\
\hline NICU admission & 8 & 8.33 & 3 & 3.12 & 0.21 \\
\hline Spontaneous abortion & 2 & 2.08 & 2 & 2.08 & $>0.99$ \\
\hline
\end{tabular}

Table 3 : Distribution of women according to mode of Delivery

\begin{tabular}{llllll}
\hline Mode of Delivery & \multicolumn{2}{l}{ Study Group $(\mathbf{n}=94)$} & \multicolumn{2}{l}{ Control Group $(\mathbf{n}=94)$} & P \\
& Number & Percentage & Number & Percentage & value \\
\hline Vaginal delivery & 83 & 88.29 & 86 & 91.48 & 0.46 \\
Caesarian for foetal distress & 6 & 6.38 & 6 & 6.38 & $>0.99$ \\
Caesarian for other causes & 5 & 5.31 & 2 & 2.12 & 0.44 \\
\hline
\end{tabular}

- $\mathrm{N}=94$ as two women in each group aborted.

pregnancy ${ }^{5,12}$. Nambiar et al, in his study in Indian population, in thyroid autoimmune negative women with $\mathrm{S}$ TSH between 0.1 to 2 and 2 to $4 \mathrm{mIU} / \mathrm{L}$, reported rate of miscarriage as $7.35 \%$ and $7.5 \%$ respectively ${ }^{11}$. Deeksha et al also showed no difference in rate of miscarriage between study and control group ${ }^{10}$. Our study did not find any difference in the rate of spontaneous abortion between women in study and control group [p > 0.99 ]. In overt and subclinical hypothyroid dism, there is increased incidence of preeclam psia $^{5,13}$. However, other studies does not show such association ${ }^{10,14 .}$. High incidence of gestational diabetes mellitus (GDM) in hypothyroid women was reported by Sarojamma et al but study was not case both groups majority of women had normal BMI, 75\% in study and $55.2 \%$ in the control group. In the study group serum FT4 of all the women was within the normal reference range. The maternal and fetal outcomes and mode of delivery in both the groups were comparable [Table1-3].

\section{Discussion}

As per the latest ATA guidelines, gestation specific reference ranges should be used for interpretation of the thyroid function, the following cut offs may be used: first trimester, $<2.5 \mathrm{mIU} / \mathrm{L}$; second trimester, $<3 \mathrm{mIU} / \mathrm{L}$; third trimester, $<3 \mathrm{mIU} / \mathrm{L}^{7}$. Nagendra et al and Negro et al, reported increased pregnancy loss in women with S TSH between 2.5 and $5.0 \mathrm{mIU} / \mathrm{L}$ in the first trimester of controlled $^{5}$. Deeksha et al did not find any association between GDM and subclinical hypothyroidism $(\mathrm{SCH})^{10}$. In our study maternal complications like preeclampsia, gestational diabetes and placental abruption were similar in the study and control group [Table 1]. Sahu et al., reported higher number of caesarean section for fetal distress ${ }^{14}$. Rates of caesarian section for fetal distress in study and control group were similar in study by Deeksha et $\mathrm{al}^{10}$. In our study the rates of vaginal delivery and caesarean section were similar in both the groups [Table 3]. Our study shows no difference in rates of caesarian section for foetal distress in study and control group [p $>0.99]$. 
In a case control study by Nambiar et al., with S TSH between 0.1 to 2 and 2 to $4 \mathrm{mIU} / \mathrm{L}$ in pregnant thyroid autoimmune negative women rates of preterm delivery were $5.14 \%$ and $10 \%{ }^{11}$. Increased risk of preterm birth in women with $\mathrm{SCH}$ as compared to control has been reported by Sarojamma et $\mathrm{al}^{5}$. In a study by Negro et al, with S TSH between 2.5- $5 \mathrm{mIU} / \mathrm{L}$ compared with TSH $<2.5 \mathrm{mIU} / \mathrm{L}$ rates of preterm were comparable ${ }^{12}$. In our study, the risk of preterm birth was not increased in the women with new $\mathrm{S}$ TSH criteria range $[\mathrm{p}=0.62]$.

In the present study the incidence of fetal distress, low APGAR score at 5 minutes and NICU admission were comparable in both the groups [Table 2]. Trimester specific reference ranges for S TSH during pregnancy have established in countries like USA, China, Switzerland and Korea which were found to be lower than their non-pregnant counterparts ${ }^{2,6,7}$.

In India, Kumar et al, and Marwaha et al, reported the trimester specific S TSH reference ranges that are higher than that of reports from western literature ${ }^{15,8}$. The $\mathrm{S}$ TSH during pregnancy in Indian women is high due to reduced availability of iodine and it significantly overlaps with that of non pregnant. The trimester specific reference range for S TSH, established by Marwaha et $\mathrm{al}^{8}$ using 5 th and 95th percentile, as 0.6-5.0, 0.44-5.78 and 0.74-5.7 $\mathrm{mIU} / \mathrm{L}$, in the first, second and third trimester of pregnancy, respectively; these values are higher than those reported by other countries.

\section{Conclusion}

The present study was designed to compare the effect of S TSH $>3 \mathrm{mIU} / \mathrm{L}$ on feto-maternal outcome by applying the lower S TSH threshold in Indian population; but compared to controls no statistically significant difference in the maternal and fetal outcome were observed. The study was based on a small sample size. The study was single centre hospital based and duration of study is limited. Due to these limitation results could not be generalized and taken as representative. Indian guidelines for screening and treatment of pregnant women for thyroid disorders through large multi centric RCT is need of the hour.

\section{Acknowledgements}

We hereby would like to thank Dr.Suman Gaddi, Professor and HOD, Department of OBG; Dr.Sreenivasalu, Superintendent of VIMS; Dr. Krishna
Swamy, Director \& Principal VIMS, Bellary to allow us to publish this paper.

\section{Conflict of interest: None. Disclaimer: Nil.}

\section{References}

1.Dhanwal DK, Prasad S, Agarwal AK, Banerjee AK. High prevalence of subclinical hypothyroidism during first trimester of pregnancy in North India. Indian J Endocrinol Metab. 2013; 17(2): 281-84.

2.Chang DLF, Pearce EN. Screening for Maternal Thyroid Dysfunction in Pregnancy: A Review of the Clinical Evidence and Current Guidelines. Journal of Thyroid Research. 2013; Article ID 851326.

3. Thammiah J. Screening for thyroid disorders in pregnancy with TSH estimation. Int J Reprod Contracept Obstet Gynecol. 2016; 5: 1052-5.

4.Patel RD, Deliwala KJ, Shah PT, Singh RK. Fetomaternal outcome of thyroid disorder in pregnancy. Int J Reprod Contracept Obstet Gynecol. 2016; 5: 4466-9.

5.Chunchaiah S, Prasad N, Murali BM, Rupakala BM, Rangaiah N. A prospective observational study of thyroid dysfunctions during pregnancy in a tertiary care hospital. International Journal of Reproduction, Contraception, Obstetrics and Gynecology. 2016; 5(11): 3683-9.

6.Kim HS, Kim BJ, Oh S, Lee DY, Hwang KR, Jeon HW, et al. Gestational Age-specific Cut-off Values Are Needed for Diagnosis of Subclinical Hypothyroidism in Early Pregnancy. J Korean Med Sci. 2015; 30(9): 1308-12.

7.Stagnaro-Green A, Abalovich M, Alexander E, Azizi F, Mestman J, Negro R, et al. Guidelines of the American thyroid association for the diagnosis and management of thyroid disease during pregnancy and postpartum. Thyroid. 2011; 21(10) :1081-25.

8.Marwaha RK, Chopra S, Gopalakrishnan S, Sharma B, Kanwar RS, Sastry A, et al. Establishment of reference range for thyroid hormones in normal pregnant Indian women. BJOG. 2008; 115(5) :602-6.

9.Prema S. Thyroid Sceening in Pregnancy- A Study of 82 Women. J Obstet Gynecol India. 2010; 60(3): 232-7.

10.Joshi D, Dewan R, Bharti R, Sharma M, Biswas K, Batra A, et al. Feto-maternal Outcome Using New Screening Criteria of Serum TSH for Diagnosing Hypothyroidism in Pregnancy. Journal of Clinical and Diagnostic Research. 2015; 9(4): QC01-QC03.

11.Nambiar V, Jagtap VS, Sarathi V, Lila AR, Kamlanathan S, Bandgar TR, et al. Prevalance and impact of thyroid 
The New Indian Journal of OBGYN. 2019 (January-June); 5(2)

disorders on maternal outcome in Asian indian pregnant women. J Thyroid Res. 2011; 2011:429097.

12.Negro R, Schwartz A, Gismondi R, Tinelli A, Mangieri $\mathrm{T}$, Stagnaro - Green A. Increased pregnancy loss rate in thyroid antibody negative women with TSH levels between 2.5-5.0 in the first trimester of pregnancy. J Clin Endocrinol Metab. 2010; 95: E44-48.

13.Wilson KL, Casey BM, McIntire DD, Halvorson LM, Cunningham FG. Subclinical thyroid disease and the incidence of hypertension in pregnancy. Obstet Gynecol. 2012; 119(2): 315-20.

14.Sahu MT, Das V, Mittal S, Agarwal A, Sahu M. Overt and subclinical thyroid dysfunction among Indian pregnant women and its effect on maternal and fetal outcome. Arch Gynecol Obst. 2010; 281: 215-20.

15.Kumar A, Gupta N, Nath T, Sharma JB, Sharma S. Thyroid function tests in pregnancy. Indian J Med Sci. 2003; 57: $252-8$.

Shiva Kumar H C Hiriyur Chidanandaiah ${ }^{1}$, Chandrashekhar T Tharihalli ${ }^{2}$, Suman Gaddi ${ }^{3}$, Chandrashekhar $\mathrm{K}^{4}$

${ }^{1}$ Associate Professor; ${ }^{2}$ Professor; ${ }^{3}$ Professor and HOD;

${ }^{4}$ Assistant Professor; Department of Obstetrics and Gynaecology, Vijayanagara Institute of Medical Sciences, Bellary, Karnataka, India. 